\title{
ERECTION OF FOUNDATION-BASEMENT PART OF UNDERGROUND STRUCTURES IN WATER-SATURATED SOILS OF ODESSA REGION
}

\author{
The Odessa State Academy of Civil Engineering \& Architecture, \\ ${ }^{1}$ Department of Architectural Structures, \\ ${ }^{2}$ Department of Reinforced Concrete Structures and Transport Facilities, \\ spring.cherneva@gmail.com
}

(C) Plahotny G., Chernieva O., Chorna L., 2021

According to the General Plan of the city's perspective development, it is planned to develop the territories of the irrigation fields and the adjoining dam. The article details the engineering tasks of erecting the foundation-basement construction of underground structures considering the geological and hydrogeological conditions of the low-lying area of the Odessa region. Features of occurrence and genesis of low-lying part sites have been elaborated. The paper also elucidates the methods of orientation employed and water lowering during the erection of underground structures.

Technological order of work execution for reliable and effective structural scheme of underground structures in water-saturated soils is proposed.

A device for vertical waterproofing of external walls and horizontal waterproofing of the floor of an underground structure has been developed.

Key words: foundation and basement part of underground structure, drainage, wellpoint, pit, waterproofing, hydrostatic pore pressure of water, water-saturated soils.

\section{Problem statement and relevance of the research}

Filtration (irrigation) fields are special areas set aside for the discharge of polluted wastewater and inhabited by soil aerobic bacteria. If it enters the soil, harmful organic matter of wastewater is exposed to the oxidation of microorganisms resulting in the formation of carbon dioxide. Simultaneously with the processes of wastewater organic treatment, the synthesis of bacterial biomass takes place (Bondar, 2013). Irrigation field development projects have been considered by the authorities of Odessa several times. The city is actively developing and requires new territories for the construction of roads and related infrastructure. In this context, hundred hectares of vacant land located in close proximity to the center is attractive, and construction on this open land is imperative in the near future. To ensure that this open area is made fit for construction, it is necessary to solve a huge number of problems associated not only with the chemical composition of these soils, but also with the geographical location of this territory in relation to the estuary and sea level.

\section{The purpose of the study}

To analyze the engineering tasks and methods of dewatering during the construction of underground structures and to propose a scientific sequence for the work execution. The study also recommends an effective device for the vertical and horizontal waterproofing of the outer walls and floor of underground structures. 


\section{Analysis of recent research and publications}

When building on soils of this type, it is necessary to solve two main problems: consolidation and strengthening of the soil base. The consolidation issue of weak water-saturated clay soils of high thickness has been well studied in the work of Russian researches. The development of deformations, stress conditions and variation of pore pressure within the bulk of the weak water-saturated soils have also been studied (Abelev, Averin, Chunyuk, 2018). The experience of consolidating irrigated lands, used for agricultural purposes, has been described in the works of our Turkish colleagues (Satana, Ceylan, Sert, 2017). An innovative method of bioprocessing wastewater treatment of food enterprises in a membrane bioreactor was investigated by Bondar S. (Bondar, 2013).

To strengthen weak water-saturated soils, innovative modern materials and structures are being used. One of the methods employed the strengthening of weak saturated soils by using stone columns (Sinyakov, 2016).

Yet another is the use of the composite solutions with the addition of waste, boehmite, formed in hydrogen produced from aluminum to establish "wall in soil" and to prevent its horizontal shift, and to effectively strengthen the bases of existing buildings standing on water-saturated soils (Panfilova, 2020).

Currently, new techniques for the construction of sand drains have been developed to strengthen weak water-saturated soils. These include deepening using an open pipe, drilling with a solid or spiral drill, reclamation, etc. In addition, a number of vertical drain structures have been developed. This includes traditional circular sand drains, sand cracks, "sandwicks" prefabricated sand drains, a large group of flat drains with filters of various materials (cardboard, plastic, non-woven, etc.) and cores of various shapes with appropriate installation technologies (Kislyakov, 2014).

The principles of designing foundations on water-saturated soils were described in the work of colleagues from Belarus, possible ways of foundations' compaction were also analyzed (Chesheiko, 2017).

\section{Hydrogeological observations}

Within the Odessa region there are a number of large seaside estuaries - Dniester, Sukhoi, Hadzhibeysky, Kuyalnitsky, Tiligulsky. Estuaries occupy the lower reaches of the river valleys or ravines and are separated from the sea by mottled silty-sand-shell bulkheads-bay bars. Some have continuous, while others have intermittent ducts (delta arms).

The city borders of Odessa include the southern parts of two estuaries adjacent to the embankment Hadzhibeysky and Kuyalnitsky. They are separated by a narrow watershed ending in Zhivakhova Mountain (43 $\mathrm{m}$ high), and united by a common bay bar.

Underground water is confined to estuary-sea sediments and lies at a depth of $0.6-0.8 \mathrm{~m}$ from the surface. The level and dynamic of groundwater depends on surge events in the Hadzhibey and Kuyalnitsky estuaries and the Odessa Bay, with which the waters of the site are hydraulically connected.

Previously, both estuaries flowed into the sea: Hadzhibey - through the Isakov Harbor, and Kuyalnitsky - through the Istrian Harbor (Fig. 1, a). The intense effect of the wind (north-west insolation) for centuries separated them from the sea with mottled aeolian deposits and bulkheads.

Khadzhibey estuary occupies the lower valley of the M. Kuyalnik river, as well as its right tributary the Pig river, the so-called Palievsky bay. Estuary banks are high (up to $40 \mathrm{~m}$ ) and prone to erosion, landslide and abrasion processes.

Since the end of XIX century wastewaters from Odessa were discharged to the low landside part, forming here the so-called irrigation fields. In 1894 their volume was only 0.025 million $\mathrm{m}^{3}$, in 1940 it reached 30-35 million $\mathrm{m}^{3}$. City runoff and spring flooding in the spring of 1940 raised the water level in the estuary to $0.1 \mathrm{~m}$. After explosion of the protective dam in autumn 1941, water from the estuary through a low part of the dam gushed into the neighboring Kuyalnitsky estuary. In the postwar period, the dam was restored. Since 1965, the volume of water in the Khadjibey estuary had been constantly 
increasing. The main reason for the rise in the level and more than three times the volume of water in the estuary was an increase in urban wastewater -20 million $\mathrm{m}^{3}$ in 1968 and 120 million $\mathrm{m}^{3}$ in the early 1980s. The estuary-sea channel was opened to lower the level, which rose by $+1.4 \mathrm{~m}$ in $1963-64$, and the protective dam on the estuary's south shore was raised another $3 \mathrm{~m}$ to prevent flooding of the overflow.

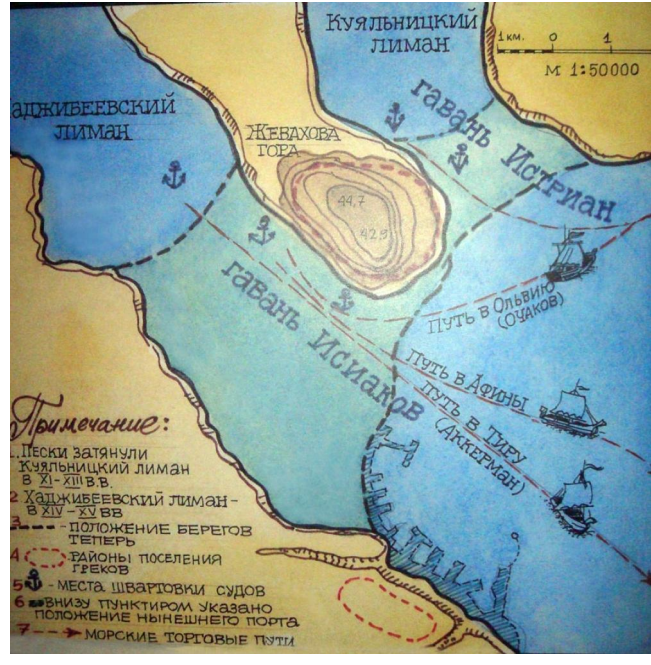

$a$

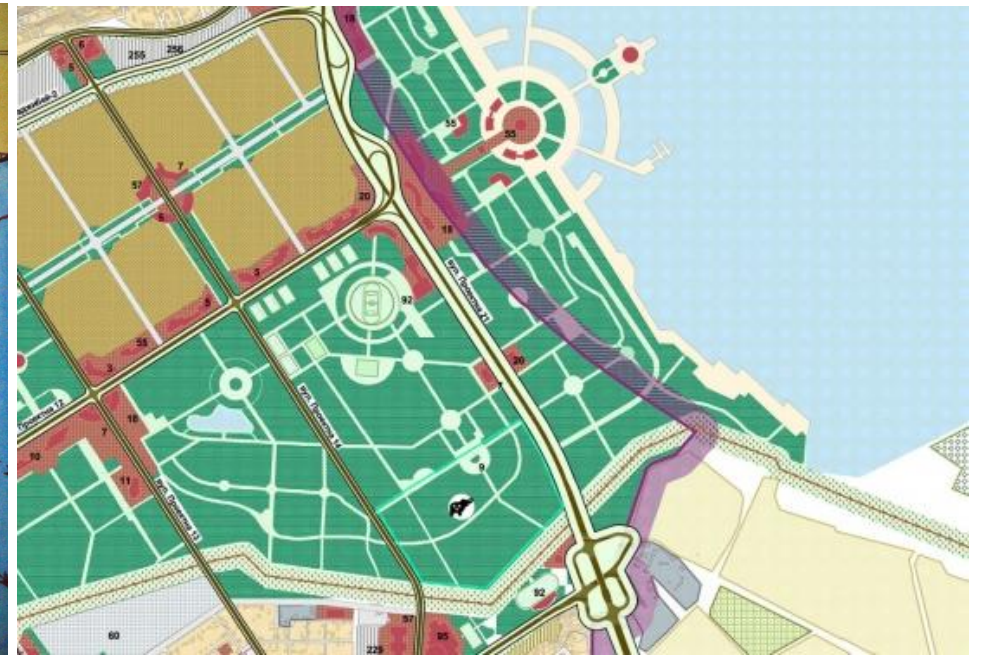

$b$

Fig. 1. Plan of ancient harbors on the site of present Odessa (Kobulianov, 2016) (a); Development of the irrigation fields according to the General Plan of the city's perspective development $(b)$

To treat wastewater near the estuary, the Severnaya treatment plant was built, which included filtration fields - former irrigation fields - in the zone of influence of the mechanical treatment stages. However, untreated water continues to flow into the estuary. The increase in the level led to a sharp intensification of such adverse processes as abrasion and banks' collapse.

Kuyalnitsky estuary is located in the lowlands of the valley of the Big Kuyalnik river. This part of Odessa bay has the width of 1.5-2.5 km. The average water level is $5.3 \mathrm{~m}$ below the sea level. The shape of the coastal lines of the estuary is winding, the coasts themselves are high (up to $40 \mathrm{~m}$ ).

According to the General Plan of the city's perspective development (Fig. 1, $b$ ), it is planned to develop the irrigation fields' territories and the adjoining dam. On the lower part of these areas is a high level of groundwater (0.5-1.0 m below the day surface), and the entire territory is layered with variegated strata of water-saturated soils.

Structural solutions of the foundation and basement part of underground structures built in watersaturated soils are determined by the nature of deformations of the site ground surface, engineering and geological conditions, drainage, material and technological sequence of works. The sequence of these factors is very diverse, especially in aeolian soils.

Aeolian soils (sands, silts, technogenic clays) are usually loose, porosity 45-50\%, filtration coefficient $10-15 \mathrm{~m} /$ day. On the contrary, filtration capacity of homogeneous clay soils is insignificant, practically they can be considered as waterproof. Therefore, when carrying out surveys at the surveyed site, first of all, determine its stratification, physical and mechanical properties of soils of separate layers (cohesion, moisture, density of dry soil, etc.).

\section{Materials and methods}

Construction practice requires arrangement of drainage systems within the site. The depth of the site drained excavation should be at least $0.5 \mathrm{~m}$ below the level of the net floor of the projected structure. Dewatering norms are assigned considering territory use and water properties of soils, including capillary elevation and deep backwater effect. 
There are a number of technological methods of artificial dewatering (Kliorina, 2002):

1. Deep dewatering - groundwater is pumped out of the wells arranged in the soil mass with the help of wellpoints. The wellpoint method is carried out using lightweight wellpoint units. They have tubular wellpoints immersed in boreholes drilled in the watered soil.

All wellpoints are connected to a suction manifold to which all centrifugal pumps for water and air pumping lead.

2. Vacuum dewatering method is used when working in fine-grained soils, where it is inexpedient to use light wellpoints. The principle of vacuum dewatering is to use wellpoints of a special design with ejector water elevators, complexes of pipeline sections (collectors) and centrifugal pumps.

The ejector wellpoint is located on the ground. It consists of a pipe with a filter link. Inside the wellpoint there is another pipe, connected at the bottom with an ejector water lifter. It consists of a nozzle to supply water to the diffuser. During the operation of the wellpoint, a pump delivers pressurized water into the annular cavity between its outer and inner centrifugal tube. Having reached the nozzle, it flows up through it to the diffuser, and a vacuum is formed between the nozzle and the diffuser neck, under the action of which water enters the inside of the wellpoint through its filtered link. Mixing with the pressure water, it flows upward and enters the manifold, which collects it from all the wellpoints and sends it offsite.

When vacuuming, in contrast to the compaction load, there is no soil venting around the perimeter of the compacted surface area, which significantly increases the efficiency of this method. And the use of flexible screens (geo-membrane) opens up opportunities for construction. A series of compression tests was carried out (Cherkasova, 2018) to identify the similarities and differences in the consolidation processes when compacting different materials by vacuuming and equivalent load created by the press.

\section{Recommendations for site execution}

When digging the excavation, it is necessary to provide, depending on the degree of cohesion of soils, the device of slopes. The bottom of the excavation should be on the whole perimeter of $1.0 \mathrm{~m}$ more than the design dimensions of the underground structure. Across the entire area of the bottom is placed monolithic reinforced concrete slab of lean concrete, $500 \mathrm{~mm}$ thick, or compacted rubble preparation of gravel of small fraction, on which the cement-sand screed is laid, with subsequent sealing of the surface.

Walls of the foundation and basement must be of reinforced monolithic concrete, or brick, with a thickness of at least $510 \mathrm{~mm}$ on the cement-sand mortar. Under the walls and over the entire area of the bottom lay several layers of waterproofing on bitumen mastic. When the length of the walls exceed $6.0 \mathrm{~m}$, buttresses shall be provided in the underground part of the building to increase the stability of the walls at hydrostatic pressure of water and the backfill soil.

It is necessary to take measures to isolate the floor and walls of the underground structure from the capillary moisture being in the ground to prevent its soaking and rising along the walls. These measures should be taken seriously.

Due to the high demands on the dryness of the structures of the underground building, it is recommended to install the vertical waterproofing of the outer walls (from the ground side) in the form of a continuous waterproofing mat of rot-proof roll-fed and sheet waterproofing materials glued in layers with bitumen or mastic on the even, coated with the fluidized bitumen and dried surface of the walls to be isolated. Continuous carpet of several roll materials glued with bitumen mastic is a perfect and reliable waterproofing if the work is done well.

Protective barrier to ensure external waterproofing of the walls when lining the cavity should be provided in the form of a brick wall with a thickness of $1 / 2$ brick.

Protective wall and the rest of the slots to close tightly compacted and tamped crumpled meotic clay, creating a so-called "clay lock". 
According to the height of the outer walls should exceed the mark of the day ground surface not less than $1.0 \mathrm{~m}$.

To ensure reliable protection of horizontal waterproofing of the floor of the underground structure from the possibility of its surfacing during hydrostatic pore water pressure $\left(\gamma_{\text {hydrostatic }}=\mathrm{H}_{\mathrm{m}} \times \rho\right.$, where $\rho=0.1 \mathrm{~kg} / \mathrm{cm}^{2}$ ), it is necessary to load it with a monolithic reinforced concrete slab, the specific pressure of which should exceed the hydrostatic pressure of pore water at the depth $\mathrm{H}_{\mathrm{m}}$.

After carrying out these works with provision of technological sequence, it is allowed to remove the wellpoints from the ground and dismantle the drainage system. The remaining types of construction and installation works (installation of flooring, elevators, stairwells, partitions, communications) can be performed from the day surface.

\section{Possible problems and prospects for further research}

1. In dangerous proximity to the irrigated fields there is the Khadzhibey dam, the technical condition of which is unsatisfactory, and in some places, it is critical. Despite the repairs carried out in 2016, it could not withstand the first storm. The dam keeps the water level in the estuary at an elevation of only a meter higher than the elevation of the irrigated fields themselves. And its breakthrough will lead to the complete flooding of these lands.

2. When performing work on irrigated fields, it is necessary to remove a large top layer of soil, since it is saturated with waste from the Odessa Oil Refinery and Paint \& Varnish plants, and therefore there is a problem of further storage of this soil or reclamation of these lands, which can take years.

3. Lowering the estuary level to the sea level, which must be started urgently, with the use of the existing, suitable for this, engineering infrastructure, the capacity of which will allow leveling the estuary horizon with an average multi-year sea level in several years (Skachek, 2015) (taking into account the inadmissibility of contaminated estuary water entering the Odessa Bay in summer and the need to agree on the schedules of discharge from the Khadzhibey estuary and the supply of seawater to replenish the Kuyalnitsky).

4. Bringing to the maximum degree of purification of wastewater entering the biological treatment plant (SBP) "Severnaya".

\section{Conclusions}

1. When erecting foundation-basement part of underground structures in the low-lying part of the Odessa region we should consider geological and hydro-geological conditions of the building sites.

2. It is recommended to apply various methods of dewatering with the use of drainage systems when constructing excavations.

3. The structure of the floor and walls of the underground structures shall be protected against their moistening by the pore underground waters by means of the adhesive waterproofing device.

4. All construction works on the territory of irrigation fields should be carried out after complete soil detoxification and consolidation.

5. Implementation of any work is possible only after the complete reconstruction of the Khadzhibey dam.

6. All proposed technologies and measures for the erection of foundation-basement part of underground structures must be carried out in compliance with all the requirements of current regulations and State Standards of Ukraine (DBN B.1.1-5-2000, DBN B.2.1-10-2009, DSTU-N B B.1.1-40: 2016).

\section{References}

Bondar, S., Chabanova, O. (2013). Innovative waste water treatment methods for food industry. Food Science and Technology 4(25), 94-98 (in Russian). 
Abelev, M. Y., Averin, I. V., Chunyuk, D. Y. et al. (2018). Study of the Processes of Consolidation of a Thick Mass of Water-Saturated Clay Soils when Erecting Unique Structures. Soil Mech Found Eng 55, 333-339. https://doi.org/10.1007/s11204-018-9545-X

Satana, S., Ceylan, A. R., Sert, A. (2017). The Turkish experience in consolidation of irrigated land: Productivity and efficiency implications. World bank conference on land and poverty. Washington DC, March 20-24.

Sinyakov, L., Garmanov, G. and Melentev, A. (2016). Strengthening and Stabilization of the Weak Water Saturated Soils Using Stone Columns. MATEC Web of Conferences, 73, 01003. https://doi.org/10.1051/ matecconf/20167301003

Panfilova, M., Zubrev, N., Efremova, S. et al. (2020). Strengthening of water-saturated soils of the bases of underground structures with composite solutions modified by industrial waste, boehmite. Case Studies in Construction Materials (Volume 12, June 2020, e00323). https://doi.org/10.1016/j.cscm.2019.e00323

Kislyakov, A., Grakhov, V., Kislyakova, Yu. (2014). Application of vertical drains when compacting low water-saturated soil. Intelligent systems in production 1 (23), 124-126. (in Russian).

Chesheiko, A., Repyakh, A. (2017). Construction in weak water-saturated soils. Working Paper. P. 54-57. Retrieved from https://www.openrepository.ru/article?id=72764 (in Russian).

Kobulianov, I. (2016). How old is Odessa 6 hundred or 6 thousand? Retrieved from http://co6op. narod.ru/txt/odessa/articles/odessa.html (in Russian)

Kliorina, G. (2002). Drainage in engineering preparation and improvement of the territory of buildings Moscow, 2002, 144 p. (in Russian).

Cherkasova, L. (2018). Compaction of water-saturated soil by surface vacuuming. MATEC Web of Conferences 196, 03006. https://doi.org/10.1051/matecconf/201819603006

Skachek, A. M., Freidlin, M. P. (2015). Priority tasks, ecological, recreational, urban and transportation aspects of rehabilitation and development zones of Hadzhibeysky estuary. Materials of the all-Ukrainian scientific-practical conference "Natural resource potential of Kuyalnytsky and Hadzhibeysky estuaries, inter-estuary territories: current state, development prospects" UKRMEPA, Odesa, 103-106 (in Russian).

DBN B.1.1-5-2000 Buildings and Structures in Fragranted Territories and Sedimenting Soils. Part 2. Kyiv, 2000 (in Ukrainian)

DBN B.2.1-10-2009 Bases and Foundations of Buildings. Basic design provisions. Kyiv, 2009 (in Ukrainian)

DSTU-N B B.1.1-40: 2016 Guidelines for the design of buildings and structures on weak soils. Kyiv, 2017 (in Ukrainian)

Г. Н. Плахотний ${ }^{1}$, О. С. Чернєва ${ }^{2}$, Л. В. Чорна ${ }^{1}$

Одеська державна академія будівництва та архітектури, ${ }^{1}$ кафедра архітектурних конструкцій,

${ }^{2}$ кафедра залізобетонних конструкцій та транспортних споруд

\title{
ЗВЕДЕННЯ ФУНДАМЕНТНО-ПІДВАЛЬНОЇ ЧАСТИНИ ПІДЗЕМНИХ СПОРУД У ВОДОНАСИЧЕНИХ ГРУНТАХ ОДЕСЬКОГО РЕГІОНУ
}

\author{
(С Плахотний Г. Н., Чернєва О. С., Чорна Л. В., 2021
}

Згідно із Генпланом перспективного розвитку Одеси передбачено освоєння територій полів зрошування і пересипу, що примикає. На низинній частині цих територій високий рівень підземних вод (0,5-1,0 м нижче від денної поверхні), а вся територія утворена строкатими нашаруваннями водонасичених грунтів. Конструктивні рішення фундаментно-підвальної частини підземних споруд, що будуються у водонасичених грунтах, визначаються характером деформацій земної поверхні ділянки, інженерно-геологічними умовами, дренажем, матеріалом і технологічною послідовністю виконання робіт. Черговість цих факторів доволі різноманітна, особливо в грунтах еолового утворення. Добавки еолових грунтів (пісків, мулів, глин техногенних) зазвичай пухкі, пористість 45-50\%, коефіцієнт фільтрації 10-15 м/добу. Натомість, фільтраційна здатність однорідних глинистих грунтів незначна, практично 
їх можна вважати водонепроникними. Тому, здійснюючи дослідження на майданчику, який обстежується, визначають, передусім, iї шаруватість, фізико-механічні властивості грунтів окремих шарів (зв'язність, вологість, щільність сухого грунту тощо) Технологія виконання робіт передбачає влаштування дренажних систем в межах майданчика.

У статті розглянуто інженерні завдання зведення фундаментно-підвальної конструкції підземних споруд з урахуванням геологічних і гідрогеологічних умов низинної частини Одеського регіону. Викладено особливості виникнення і генезис майданчиків низинної частини. Описано способи орієнтування і водозниження під час зведення підземних споруд.

Запропоновано технологічну послідовність виконання робіт для забезпечення надійної та ефективної конструктивної схеми підземних споруд у водонасичених грунтах. Розроблено влаштування вертикальної гідроізоляції зовнішніх стін і горизонтальної гідроізоляції підлоги підземної споруди.

Ключові слова: фундаментно-підвальна частина підземної споруди, дренаж, голкофільтр, котлован, гідроізоляція, гідростатичний поровий тиск води, водонасичені грунти. 